Islands, New Hebrides, New Caledonia to New Zealand, and it is thought that a source of information of great value, which might provide the key to problems of biological distribution and ecology in this area, could be found in the Solomon Islands. Much of these extensively forested Islands has not yet been seriously disturbed by man, but its forests are already attracting the attention of those who wish to exploit them commercially, so that it is a matter of some urgency to investigate them while present conditions last. An examination of existing knowledge indicates that the first expedition to the Solomon Islands might most profitably spend about six months in the field, and consist of a marine party of about six to seven scientists to study the shallow water and shore-line biology, and a land party of about eight botanists and zoologists to concentrate on the densely forested interiors and the altitudinal variations. Areas for intensive investigation have been selected on the Islards of Guadalcanal, San Cristoval, Ysabel and Kolombangara, and the marine party will concentrate on areas of the shores of these islands together with New Georgia and Russell Island. The plans for the expedition are proceeding. The expedition will be led by Mr. E. J. H. Corner (Cambridge), who will also lead the land party, while the marine party will be under the leadership of Prof. J. E. Morton (Auckland). The personnel will include scientists from Britain, Australia and New Zealand, some of whom have already been selected, as well as scientists from the British Solomon Islands Protectorate Government Departments of Forestry, Agriculture and Geology. The planning of the expedition is in the hands of the Southern Zone Expeditions Committee of the Royal Society and a small planning group appointed by the committee, comprising the chairman of the committee, the leader and the executive secretary of the Royal Society. The logistics and field organization of the expedition will be the responsibility of Mr. G. E. Hemmen, expeditions officer of the Royal Society, and it is expected that the expedition's boat will be the M.V. Maroro from Fiji, under the command of her owner, Captain S. B. Brown.

\section{National Institute of Agricultural Engineering}

AN informal meeting was held on July 24 at the National Institute of Agricultural Engineering, Wrest Park, Silsoe, at which Sir Harold Wernher, chairman of the Institute, made a presentation on behalf of the staff to Mr. W. H. Cashmore in view of the latter's retirement from the directorship of the Institute on July 31 . Presentations were also made to Mr. J. W. Andrews, secretary, and to Mr. R. V. Hussey, who were also retiring. Those present included the Hon. J. J. Astor, J.P., chairman of the Governing Body, and Mr. C. J. Moss, director designate.

\section{Medical Research Council New Research Unit and Research Groups}

THE Medical Research Council has recently announced the ostablishment of a now research unit and of three new research groups: The Cell Genetics Research Unit will be set up in the Department of Genetics in the University of Clasgow, under the honorary direction of Prof. G. Pontecorvo. The Unit will undertake research on the use of human and other mammalian cell cultures as a tool in genetic analysis. The Oculogenital Virus Research Group has been established at the Institute of Ophthalmology, University of London, under the honorary direction of Prof. B. R. Jones. The Group will be engaged on research on the trachoma-inclusion conjunctivitis agents, with particular reference to the relationship between infections of the genital tract and infections of the oye. The Research Group in Basic Immunology has been set up in the Department of Experimental Pathology, University of Birmingham Medical School, under the honorary direction of Prof. P. G. H. Gell. The Group will be mainly concerned with fundamental research in immunology and immunogenetics, with particular reference to the activities of cells in mediating immune responses. The Thrombosis Research Group will be established at the Institute of Basic Medical Sciences, the Royal College of Surgeons, under the honorary direction of Prof. G. V. R. Born. The Group will be concerned with research into chemical substances which promote or prevent the adhesion and aggregation of platelets in the blood and affect the formation of thrombi.

\section{Political and Economic Pianning}

THE annual report of Political and Economic Planning for the year ended March 31, 1964, notes that all five major current projects are due for completion in the next few months; an investigation has been made both of the organization's methods of working and of the appropriate balance between intensive studies and policy reviews (Pp. 17. London: Political and Economic Planning, 1964). Policy review groups are being set up on fuel and world population, and a number of new major projects within the general ambit of "The Shape of the Sixties" are being considered. Under the programme of work on Britain and the European Common Market, started in September 1958 , there were three publications during the year, and a book-length report on economic planning and the European economic community is being prepared. A full report on the examination of community mental health sorvices is also in preparation, and completion of another dealing with an investigation of prisoners and their families is also expected this summer. A final report on attitudes in British industry is expected to be published by the end of the year, and the report on "Education for a Developing Region" is to be followed by one giving the findings of tho investigations in the United Kingdom. Publication of the results of a three-year study, Trade Unions in a Changing Society, started in October 1960, was completed with the issue of three Broadsheets during the year (Nature, 200, 817; 1963).

\section{Scientific American Offprints}

OfFPrints of articles published in Scientific American are selling in increasingly large quantities throughout the world, particularly in the United States, where they have been adopted in many colleges and universities as supplementary material for text-books, some of which become out of date quickly. The articles are written by leading scientists actively engaged in research. Recently issued offprint booklets range in subject from fundamental particles in physics to recent research on the mechanism of the human body in conserving the oxygen supply to the brain at times of threatened asphyxia. In each the English style is elear and simple, the argumer.t is presented logically and succinctly, and the presentation with rugard to printing diagrams is of a high quality. The documentation is useful and sufficient. In the United Kingdom, offprints are obtainable from W. H. Freeman and Co., Ltd., Warner House, 48 Upper Thames Street, London, E.C.4. Catalogue No. 4, 1964, contains a list of 865 titles arranged under subject headings, and there is an author index. The offprints cost $1 s$. $6 d$. each and cover the life sciences, chemistry, physics, technology, psychology, the social sciences, the earth sciences and the history and philosophy of science. The booklets are to be welcomed both as aids to teachers and students, who wish to keep abreast of their subjocts, and to the scientific reader who wishos to keep in touch with developments in disciplines other than his own.

\section{Magazine of Concrete Research}

WiтH the March issue of this well-known publication of the Cement and Concrete Association (16, No. 46; 1964), it now becomes a quarterly instead of a four-monthly journal, and to mark this change it appears with a new cover design; the internal appearance of the Magazine remains, however, unchanged. The reasons are common 